\title{
THE EFFECTIVENESS OF HEALTH EDUCATION ON MOTHER'S KNOWLEDGE AND FOOD INTAKE AMONG STUNTING CHILDREAN IN SOUTH LAMPUNG, LAMPUNG
}

\author{
Dian Isti Angraini, Bagus Pratama, Dwita Oktaria
}

Faculty of Medicine Universitas Lampung, Bandar Lampung

\begin{abstract}
Background: Short stature (stunting) is a condition of chronic nutritional problems that results in failure of growth in children under five who only appear after the age of 24 months. This condition is caused by a lack of nutritional intake for a long time and a lack of knowledge of the mother so that the golden period is not realized in children at the age of 0-24 months. Health education as a prevention effort has a positive impact on changes in maternal knowledge and children's food intake (energy and protein). This study aimed to analyze the effectiveness of health education on mother's knowledge and food intake among stunting children in South Lampung, Lampung.

Subjects and Method: This was an experimental study using a one group pretest-posttest design. This study was conducted in the working area of Sukadami community health center, South Lampung, from August to November 2019. The sample was 52 mothers who had stunted children aged 2-5 years and lived together. The dependent variables were maternal knowledge and food intake (energy and protein). The independent variable was maternal education. Maternal knowledge data was measured using a questionnaire and data on children's food intake was measured using a 24 hours food recall questionnaire. Data were analyzed using the Wilcoxon test.

Results: Health education was improving maternal knowledge (Mean= 15.6; $\mathrm{p}<0.001$ ); increasing energy intake $(M e a n=13.2 ; \mathrm{p}<0.001)$, and increasing protein intake (Mean= 21.5; $\mathrm{p}<0.001$ ), and they were statistically significant.

Conclusion: Health education is proven to have an effect on maternal knowledge and food intake (energy and protein) of stunting children in the working area of Sukadami community health center, South Lampung.
\end{abstract}

Keywords: health education, stunting, food intake, maternal knowledge

Correspondence:

Dian Isti Angraini. Faculty of Medicine Universitas Lampung, Bandar Lampung, Indonesia.

The $7^{\text {th }}$ International Conference on Public Health

Solo, Indonesia, November 18-19, $2020 \mid 187$

https://doi.org/10.26911/the7thicph.03.07 